\title{
Fighting Against Illicit Traffic and Forgeries of Metal Objects: The Situation in Turkey
}

\author{
Mahmut Aydin
}

Assist. Prof. Dr. Batman University, Faculty of Science and Letters, Department of Archaeology-Archaeometry Email: aydinm135@mynet.com, mahmut.aydin@batman.edu.tr

\author{
Doi:10.5901/mjss.2016.v7n2s1p340
}

\begin{abstract}
Protection of collection items belonging to museum or private collectors against fakes, forgeries and illicit traffic of cultural heritage is mostly done by archaeologists using visual inspection. Because of advanced technologies used in imitations of 20$21^{\text {st }}$ century made the task of archaeologists more difficult resulting in increased need for the employment of scientific techniques. In this respect, we need archaeometry laboratories that are fully armed with sophisticated archaeometric tools and technical knowledge. Moreover, there is also an obvious need for detailed legislation and relevant laws to be amended for fight against forgery and illicit traffic of the cultural objects at national and international level. Turkey is rich in historical monuments, antiques and ruins resulting in abundant museums and ancient objects. Being a geographical bridge between the western and the eastern world, she is also a bridge for international illicit, cultural heritage traffic and forgers. On the other hand, it is not able to build enough necessary archaeometrical infrastructures to support archaeological ones for determining authenticity and preventing misconduct regarding cultural heritage objects for museums, customs houses and so on. This study will discuss novel archaeometric techniques on authenticity determination of metal artefacts and preventing replacement of them with fake objects. Beside this, usage of non-destructive archaeometric techniques will be discussed for fighting with illicit traffic of cultural heritage, proving ownership and returning of objects. Moreover the application of methodology is explained on an international illicit traffic and forgery example of Golden Winged Sea Horse that was solved by the author.
\end{abstract}

Keywords: Cultural authenticity, counterfeit, illicit traffic, forgeries in Turkey

\section{Intruduction}

Countries without well-established archaeometry laboratories, archaeometry departments, or unable to employ archaeometrists, lacking companies that deal with authenticity and dating of objects, deprived of institutions and proper legislation and laws for fighting forgery, are more likely to become the market places for national and international forgers.

Museums across European countries request to see an authenticity certificate of objects while accepting or buying cultural heritage items. Upon obtaining the objects and their authenticity certificate, if there occurs a doubt, a new authenticity work is carried out by the experts of the museum concerned.

Only museums and certified collectors residing in Turkey are allowed to buy cultural heritage objects. Individuals may not keep cultural heritage objects at their home without getting a collector certificate from the Ministry of Culture and Tourism.

In practice, however, museums and collectors in Turkey buy objects without requesting a relevant authenticity certificate from sellers. Authenticity control is made only in the form of visual inspection mostly by archaeologists; this approach may not be always reliable considering the developed imitation technologies of $21^{\text {st }}$ century. As a matter of fact, visual inspection for authenticity purposes is done by at least three museum experts; such as archaeologist, art historian, anthropologist or a relevant expert in the field in Turkish museums. Visual inspection parameters are often weight, diameter, style critic and material estimations; the studies have to be based on subjective analyses. Since the experts may have different opinions, they may submit different reports regarding the authenticity of the same object. In such situations a visual inspection report usually needs to be supported by the use of archaeometric techniques.

\section{Main Problems of Turkey on Fake and Forgery}

1) The biggest problem facing the country is the lack of trained archaeometrists and archaeometry laboratories that can determine authenticity and fight against illicit traffic of cultural heritage objects. Determining authenticity of objects requires well educated archaeologists and archaeometrists to solve relevant problems encountered in museums and customs, and by collectors. There are up to 193 universities 
(http://www.yok.gov.tr ), 211 private museums (http://www.kulturvarliklari.gov.tr/TR,43980/ozel-muzeler.html) and 85 state museums (http://www.kulturvarliklari.gov.tr/TR,132382/) across the country. Department of Archaeometry is available only in Middle East Technical University (METU) that provides Master of Science and Ph.D. degree whereas Çukurova University and Batman University give training in this field at master's level only. Until today, only 6 archaeometrists were able to obtain Ph.D. degree at METU. It is obvious that the number of graduate degrees given in this field is far from being sufficient to meet the demands of museums or other institutions concerned.

Determining authenticity and fighting with illicit traffic of cultural heritage objects needs not only archaeometrists but also advanced archaeometry laboratories that deal with forgery and illicit traffic of cultural heritage. These laboratories should focus on getting archaeometrical precautions; for example, recording chemical composition of objects by using non-destructive archaeometrical techniques before the objects became the subjects of illicit traffic. Hence even if these objects are involved in illicit traffic and forgery, the recorded chemical composition can be used to solve the problem.

There are few laboratories in Turkey that have been established for restoration purposes. The most advanced laboratory in this field, namely Istanbul Restoration and Conservation Central and Regional Laboratory (http://www.kulturvarliklari.gov.tr/TR,108525), was established by the Ministry of Tourism and Culture and is located in Istanbul. The second one is the Ankara Restoration and Conservation Laboratory Regional Directorate (http://www.kulturvarliklari.gov.tr/TR,62800). Apart from them, a few regional restoration and conservation laboratories are being established by the Ministry of Culture and Tourism. Struggle for keeping museum collections authentic is undertaken by these few laboratories, which lack archaeometrists or experts who can focus on the authenticity and illicit traffic of cultural objects. On top of that, there is no private archaeometry firms established to work on authenticity of cultural heritage items.

2) There is also lack of proper and clear legislation and laws to prohibit reproduction of cultural goods or to describe the rules of reproduction of imitation cultural heritage items although the opposite is needed. For instance, it is advisable that imitated cultural heritage objects bear the sign of their manufacturer; these are produced as souvenir items. Otherwise even such replicas can be used to deceive museum experts or collectors. In order to prevent this type of misconduct, a suitable sign or symbol can be used to fight against illicit traffic of cultural heritage objects in the customs house. Sign on replicas can be used to distinguish replicas from authentic objects. If the sign of the manufacturer is inserted on imitated objects it will be clear that they have been produced as souvenirs. In failure to do so, this would serve to deceive museums or collectors and requires penalty. Even worse, penalties for illicit trafficking are unsatisfactory (Öztürk 2007 pp 35).

3) Replacements of authentic museum objects with fake ones are another threat for museums in Turkey. The stolen authentic objects became subject of international cultural heritage traffic. It is another emerging threat of the $21^{\text {st }}$ century which needs to be solved by archaeometrists and authorities.

\section{Methodology}

Fighting against forgery and illicit traffic of cultural heritage objects may utilize detailed chemical composition of cultural heritage objects. This is especially relevant in the case of recovered stolen objects and their return to the original site.

Since metal cultural heritage objects are rare and precious, it is almost impossible to obtain a specimen from them; therefore non-destructive archaeometrical techniques should be used on these items. In addition, many times it is impossible to move the object to the laboratory so the archaeometrical device should be portable in order to carry out analysis in-situ mode. Furthermore the archaeometric device should allow the user to make many measurements in a limited time span and get the results quickly. The device meets all this demand is Portable Energy Dispersive X-Ray Florescence (P-EDXRF) spectrometer. It is the most commonly used portable device for determination of chemical composition that can be used to fight against illicit traffic and forgery. The use of P-EDXRF is developed day after day in the analysis of cultural heritage objects.

In Turkey the legislations not lets scientists to take specimen from museum objects. Beside this moving the objects to laboratories located out of the museum needs too much official corresponding. Therefore in order to make analyses on metal objects it is necessary to use nondestructive techniques. Furthermore the devise should be portable to be able to move it to museum. The reason of choosing P-EDXRF to work on metal museum objects is that it is portable and nondestructive. 


\section{Fake Objects}

In order to combat illicit trafficking of cultural goods and fake objects, Turkish Ministry of Culture and Tourism established a website which records and demonstrates fake objects that have previously been identified by museum experts (http://www.kulturvarliklari.gov.tr/TR,44739). On this web page fake objects are classified under five different groups: Coins, ornaments, sculptures, potteries and others. The most common group of fake objects is coins.

\subsection{Coins}

Coins are the group subjected most frequently to forgery. In principle, an expert may identify a fake coin by applying a traditional visual inspection. After initial basic controls concerning the weight and style of the pieces, a numismatist will look for and examine all the details present on the surface. In fact, the technique adopted for production of a fake object generally leaves a number of characteristic macroscopic and microscopic traces which can be considered as the fingerprints of that particular technique Mezzasalma1 et al. pp 15-28).

Unfortunately dating metal objects is not possible with today's technology. Determining authenticity of coins mostly depends on the analysis of coins for obtaining chemical composition of coins. From the chemical compositions of modern and ancient metals used for production of coins, archaeometrist can determine clearly whether metals inside a coin were purified with ancient technology or not. Therefore a scientific report can be drafted about the authenticity of coins (Aydın 2013 pp 33-114). Many fake coins are identified by using analytical techniques (Figure 1-2) (Aydın 2013pp 33-114, Fleming 1975 pp 101-153).

As a general practice in Turkey, fake coins made of silver (Ag), German silver ( $\mathrm{Cu}, \mathrm{Zn}$ and Ni), solder (Pb and $\mathrm{Sn}$ ) and lead (Pb) are analyzed using the EDXRF (Aydın 2013 pp 33-114, Aydın 2014 pp 32-42). It is particularly very difficult for both archaeologists and archaeometrists to determine whether coins made of silver are counterfeit or not. In this hard job, comparing minor and trace elements of fake and authentic coins helps archaeometrist determine the authenticity of coins.

Golden coins are also produced by forgers very often. Determination of authenticity of golden coins is very difficult with visual inspection because gold does not have any corrosion products. Because of chemical characteristics of gold, basic archaeometric techniques cannot give exact answers for detection of forgery. Main and trace elemental compositions of both modern and ancient gold have to be known in order that authenticity of golden coins can be determined ( Lal et all 2011).

\subsection{Jewellery and other objects}

Brass, which looks like gold, is mostly used for producing fake jewelery. Therefore it is not easy with visual inspection techniques to find out if a golden-like object is fake or not. Other metals or metal alloys such as silver, bronze and brass are mostly used for forgery purposes likewise the modern gold metal (Aydın and Mutlu pp 97-105).

Golden objects can be analyzed through non-destructive archaeometric techniques, such as metal P-EDXRF; the results pertaining to a particular object can be compared with those of modern and ancient gold, especially in terms of their minor elements. The analysis made using P-EDXRF has proven that the chemical composition of these objects match those of modern golden objects.

\section{Replacement of Authentic Objects with Fake Ones}

On the onset of the $21^{\text {th }}$ century, one of the biggest problems encountered in Turkish museums is replacement of authentic objects with fake ones by museum experts or staff. Two important incidents occurred in the recent past. First one happened in Usak Archaeology Museum around at the end of 2005 and beginning of 2006. The Golden Winged Sea Horse Brooch which is a piece of the Lydian Hoard Treasure (King Kroisos' Treasure) was replaced with the fake one by Usak Archaeology Museum Manager (Figure 3).

The authenticity of the fake winged sea horse (Figure 3 right) was visually inspected and a report was prepared by an archaeologist on its falsity. Fake winged sea horse was also analyzed using P-EDXRF and the results were compared with analysis results of modern gold produced using the same spectrometer. As a result major and minor elements, namely Molybdenum (Mo) and Zinc (Zn) of the fake winged sea horse overlapped with minor elements of modern 22 and 18 carat gold samples.

The suspected authentic Golden Winged Sea Horse Brooch was luckily found in Germany in October 2012. 
Analysis run on the found suspected winged sea horse, modern gold and other ancients golden objects found in the same and next tumuli of the stolen Golden Winged Sea Horse Brooch were determined by using the same P-EDXRF instrument. Later on results were compared with each other. In the end, chemical composition of the found Golden Winged Sea Horse Brooch and golden objects that were found in the same and next tumuli overlapped (Table 1). Tests proved that the results are the same at $99 \%$ confidence level.

Visual inspection method employed by archaeologist and various archaeometric techniques proved its authenticity and confirmed Turkey's right to possession. Finally the object was returned to its homeland.

The second incidence of replacement of an authentic object with a fake one took place in Ankara Museum of Fine Arts and Sculpture in Turkey. Many authentic paintings were replaced with fakes (about 46 paintings) and authenticity of 23 paintings is still debated (http://www. milliyet.com.tr).

Whether an authentic object has been replaced with its fake used to be verified only by referring to their old photos in literature, its dimensions and weights in records. However, the chemical compositions of objects can easily help to prove if objects have been replaced with fake ones or not (Figure 4) (Aydın 2014 pp 32-42). If cultural heritage in museums were documented with non-destructive archaeometric techniques and relevant data were kept in an inventory, official records could easily be used to prove ownership of found stolen objects from the museums. 1745 objects were lost in Turkish museums in last ten years (2005-2015) (arkeologlardernegi.org).

\section{Fighting against Illicit Traffic of Cultural Heritage by Using Archaeometry}

Proving ownership of cultural heritage objects in order to fight against illicit traffic of cultural heritage became more important in international level. Because of the Arab Spring many museums and archaeological sites have been looted and archaeological objects became subjects of illicit traffic.

As an archaeometric method, P-EDXRF analysis results for elemental composition can be saved as a precaution for a possible replacement with fake one. Another reason of saving chemical compositions is that the results can be used to prove ownership of stolen and found objects. Methodologically, these analyses can be repeated on the same objects and the new results can be compared with old analysis results and determine authenticity and ownership of the objects (Figure 4).

\section{Conclusion}

Faking and forgery are one of the biggest problems facing Turkish museums. Bridging the western and eastern world, Turkey has become a marketplace for forgers of the east and west. In order to keep museums and collectors safe from fake cultural heritage objects and forgers, Turkey needs to improve technical infrastructure of archaeometry laboratories and amend laws concerned. In addition, museums should make regular analysis on their collections and keep these chemical records for prospective problems in order to prevent replacement of authentic cultural heritage objects with fake objects. These archived chemical compositions of stolen objects can be used for struggle against illicit traffic of cultural heritage. These data may be used in order to prove that the found object is the stolen one and the ownership of the related country is verified.

\section{References}

Aydin M. (2014). 'Using Technology Against Theft and Forgery of Cultural Heritage Goods' Mediterranean Journal of Social Sciences Vol 5, No 22, pp 32-42.

Aydin M. (2013), 'Authenticity of Roman Imperial Age Silver Coins Using Non-destructive Archaeometric Techniques' (unpublished doctoral thesis, Middle East Technical University,) pp 33-114.

Aydin M., Mutlu S. (2012) 'Determination Authenticity of Golden Coins dated to Byzantium Age by Using Non-Destructive Archaeometric and Visual Inspections Techniques. (Bizans Dönemine ait Altın Sikke Orijinalliğinin Tespitinde Tahribatsız Arkeometrik ve Görsel Analiz Yöntemlerinin Kullanılması)':, Supreme Plane of of Archaeometry in Turkey Gratuity book for Prof. Dr. Aymelek Özer ve Prof. Dr. Şahinde Demirci' Edt. Akyol A., A., \& Özdemir K., Homer Bookhome.

Lal U., S., Rao S., B., Kumar V., (2011) "Identification of Fake Gold Coins By Micro XRF Systems" Conservation of Cultural Property in India Vol 39 pp 24-25.

Mezzasalma A. M., Mondio G., Serafino T., Fulvio G., Romeo M. and Salici A. (2009) 'Ancient coins and their modern fakes: An attempt of physico-chemical unmasking'Mediterranean Archaeology and Archaeometry 9, 15-28.

Fleming S. J. (1975) Authenticity in Art: The Scientific Detection of Forgery (1st ed.)., The Institute of Physics Press, London

Öztürk Y. (2007) Protection low of Cultural Heritage in terms of Penalty Provision (Ceza Hükümleri Yönünden Kültür ve Tabiat Varlıklarını Koruma Hukuku) (1st ed.), Turhan Bookhome, Ankara. 


\section{Web Pages}

http://www.yok.gov.tr/web/guest/universitelerimiz [accessed 25 June 2015]

http://www.kulturvarliklari.gov.tr/TR,43980/ozel-muzeler.html [accessed 25 June.2015]

http://www.kulturvarliklari.gov.tr/TR,132382/15-nisan-2015-tarihinden-itibaren-tum-hafta-boyunca-ziy-.html [accessed 25 June.2015].

http://www.kulturvarliklari.gov.tr/TR,108525/istanbul-restorasyon-ve-konservasyon-merkez-ve-bolge-la-.html [accessed 10June 2015].

http://www.kulturvarliklari.gov.tr/TR,62800/ankara-restorasyon-ve-konservasyon-laboratuari-bolge-mu-.html [accessed 10 June2015].

http://www.kulturvarliklari.gov.tr/TR,44739/kategorilerine-gore-sahte-eserler.html (10 [accessed June 2015].

http://www.milliyet.com.tr/hirsizliginresmi/gundem/gundemdetay/07.08.2012/1577317/default.htm [accessed 23 June 2015]

arkeologlardernegi.org, [accessed 24 July 2015)

\section{Figures}
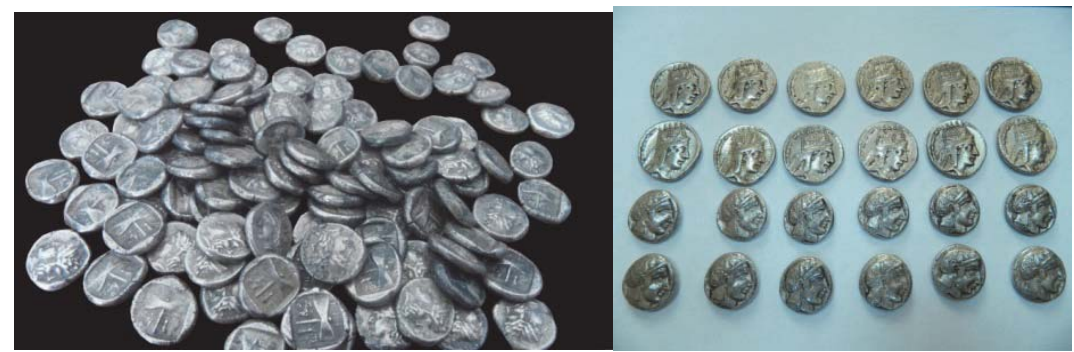

Figure 1: Fake coins from Van Museum (left) and Batman Museum (right) (Archive of Mahmut AYDIN).

a)

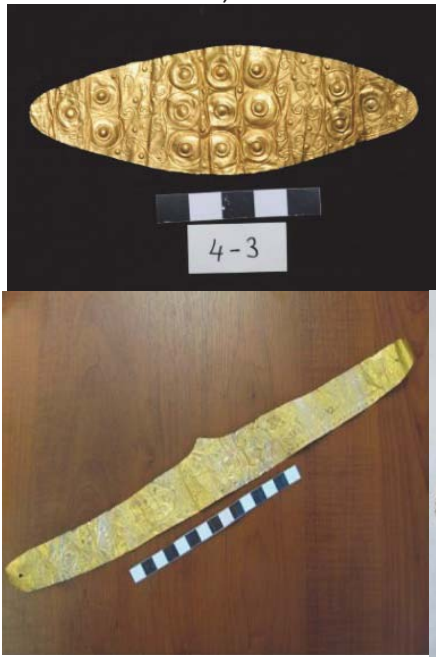

c) b)

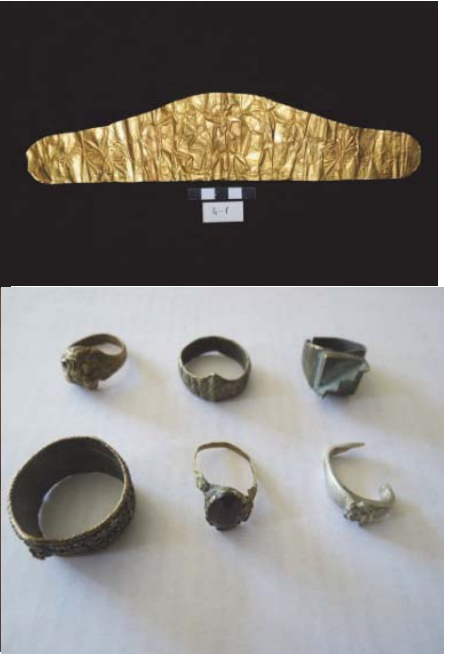

d)

Figure 2: a) Fake golden diadem from the Museum of Anatolian Civilizations, b) Fake golden diadem from the Museum of Anatolian Civilizations, c) Fake golden diadem from Izmir Museum, d) Fake rings from Çanakkale Archaeology Museum in Turkey 

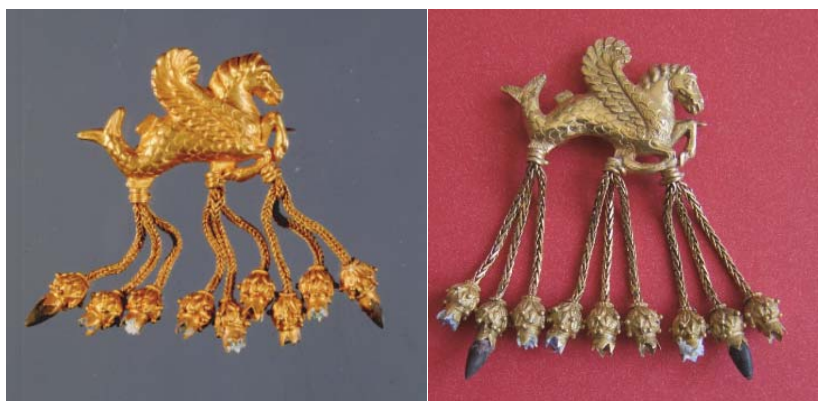

Figure 3: Authentic Golden Winged Sea Horse Brooch (left) and fake one (right) (archive of Museum of Anatolian Civilizations and Uşak Museum)

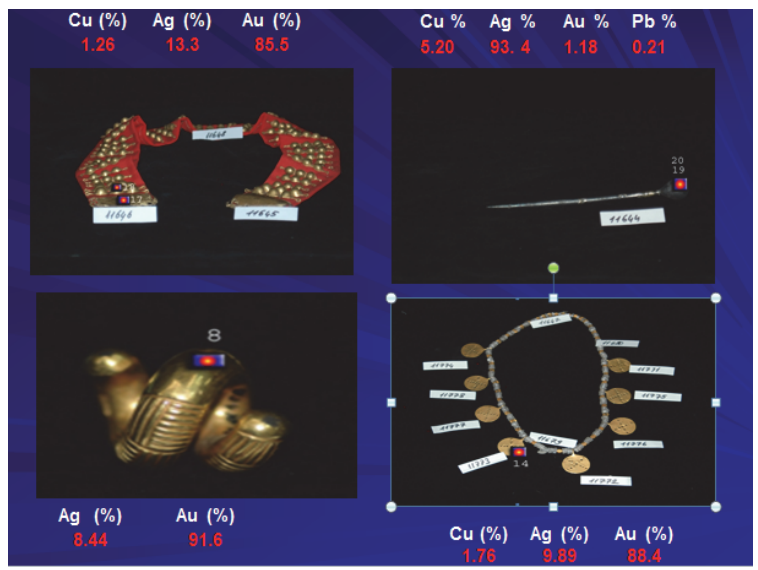

Figure 4: Recorded P-EDXRF analyses of the museum objects. In case of any replacement suspicious of these objects analyses can be repeated and their authenticity can be checked from their chemical compositions (Archive of Latif Özen, Ankara Regional Restoration and Conservation Laboratory).

\section{Tables}

\begin{tabular}{|c|c|c|}
\hline & Winged Sea Horse found in Germany (\%) & Toptepe and Next Tumuli Gold (\%) \\
\hline $\mathrm{Au}$ & 96,9 & 96,8 \\
\hline $\mathrm{Ag}$ & 2,23 & 2,26 \\
\hline $\mathrm{Cu}$ & 1,07 & 0,8 \\
\hline $\mathrm{Ni}$ & 0,02 & 0,03 \\
\hline $\mathrm{Fe}$ & 0,14 & 0,16 \\
\hline $\mathrm{Pt}$ & 0,45 & 0,67 \\
\hline
\end{tabular}

Table 1: P-EDXRF analysis results of the Golden Winged Sea Horse Brooch found in Germany and golden objects of the tumuli in which authentic object had been found and other neighboring tumuli. 